\title{
HALLGATÓI VÉLEMÉNYEK A COVID-19 VILÁGJÁRVÁNY HATÁSAKÉNT BEVEZETETT ONLINE OKTATÁSRÓL
}

\author{
DR. DEÉS SZILVIA, főiskolai tanár \\ EDUTUS Egyetem \\ dees.szilvia@edutus.hu
}

DOI $\underline{10.47273 / A P .2020 .20 .26-39}$

\begin{abstract}
ABSZTRAKT
A COVID-19 világjárvány az ajtók bezárására és a hallgatók ajtón kívül tartására kényszerítette az egyetemeket. Ennek ellenére az igény a hallgatók oktatására továbbra is fennállt. Az online oktatásnak az Edutus életében már volt elözménye, azonban ezt jellemzően a levelezős hallgatók használtak. A kutatásban arra kerestem a választ, hogyan élték meg a hallgatók a szokatlan online félévet, mi a véleményük az egyetem nyújtotta szolgáltatásokról, és hogyan értékelik a félév során megszerzett tudásukat. A teljes sokaságot az egyetem aktív hallgatók jelentette, és a populáció 15,2 százaléka válaszolt a feltett kérdésekre. Az adatok statisztikai elemzése után, az eredmények ismeretében, a hallgatói vélemények alapján legjobbnak talált megoldásokra vonatkoznak javaslataik
\end{abstract}

Kulcsszó: tanulásmódszertan, online oktatás, felsőoktatás

\begin{abstract}
The COVID-19 pandemic forced universities to close doors and keep students out of doors. Nevertheless, the need to educate students remained. Online education already had a precedent in Edutus' life, but it was typically used by correspondence students. In the research, I sought answers to how students experienced the unusual online semester, what they thought of the services provided by the university, and how they valued the knowledge they gained during the semester. The total crowd was represented by active students at the university, and 15.2 percent of the population answered the questions asked. After statistical analysis of the data, the suggestions are based on the solutions found to be the best based on the students' opinions.
\end{abstract}

Keywords: teaching methodology, online education, higher education 


\section{Bevezetés}

Az 1990-es években, amikor az első lépések megtörténtek az online oktatás irányába, még mind a diákok, mind az oktatók, mind a felsőoktatás meglehetősen szkeptikus volt a jövőt illetően. 1993-ban a Louisiana-i Egyetem hallgatói lapja például úgy fogalmazott: „Az egyetem az a hely, ahol a generációk továbbadják tudásukat, ami viszont lehetetlen gépeken keresztuil. Egy számítógép adhat át információkat, de tudást csak emberi érintkezéssel lehet közvetíteni.” (Zimmermann, 2020)

Akkor talán még senki nem gondolta, hogy 30 évvel később világszerte „lehetőségünk” adódik majd verifikálni, vagy megcáfolni az elgondolást. Ez a lehetőség, vagyis a Humphrey-féle SWOT elemzés (Friesner, 2011) harmadik eleme szerinti külső környezeti tényező, amelyet megtapasztalva törekszünk az általa okozott előnyöket kihasználni és veszélyeire felkészülni, nem más, mint a koronavírus-helyzet okozta pandémia, amely az elmúlt hónapokban intézmények ezreit kényszerítette az online oktatásra való átállásra. Fontos kérdés, hogy vajon az online oktatásra váltás előnyt vagy hátrányt jelentett a hallgatóknak. Bevezetésképpen azonban először érdemes elgondolkodni azon, válaszolnunk kell-e egyáltalán erre a kérdésre? Egy biztos, az online oktatás évről évre elterjedtebbé vált és válik az egyetemeken is. 2016-ig az USA-ban hallgató diákok mintegy harmada vett részt legalább egy online kurzuson. A profitorientált oktatási intézményeknél ez az arány 50\%, de az állami középiskolákon és egyetemeken is eléri a 11\%-ot. (Zimmermann, 2020) Mégis mi a különbség a vírus előtti és a jelenlegi helyzet között? A választás szabadsága! Azok a diákok ugyanis, akik normál körülmények között az online tanulást választják, nos valószínűleg ők komfortosan érzik magukat abban. De legalábbis van választási lehetőségük. 2014-ben a Columbia Egyemen egy 40.000 Washington állambeli egyetemi hallgató megkérdezésével zajló kutatás azt mutatta, hogy az online órákat választó hallgatók mindig rosszabbul teljesítettek, de közülük is azoknak voltak a legrosszabbak a jegyeik, akiknek összességében gyengébb képességeik és tanulmányi eredményeik voltak. Azt is kimutatták, hogy a hallgatók jellemzően a számukra kevésbé vonzó kurzusokat választották online formában (még egy ok, ami miatt rosszabbul teljesítettek). Ha valamit nem szeretnek a diákok, akkor azt online választják, és inkább meghagyják az időt a vonzóbb vagy fontosabb tárgyaknak a normál oktatásban. A kurzusokat tehát nem a minőségük, hanem a kényelmük alapján választják.

A 2020-as felsőoktatási kihívás esetében azonban nem volt meg a választás lehetősége! Minden diáknak, minden kurzust online kellett tanulni! Persze minél körültekintőbben vizsgálódunk, akkor egyértelmü lesz, hogy a pandémia alatti online oktatásról kapott kutatási eredmények 
nem lesznek a korábbi kutatásokkal teljes mértékben összehasonlíthatóak. Például azért, mert lesznek oktatók, akik addig sosem tanítottak online, így ők kevésbé lesznek gyakorlottak ezen a területen. Mégis foglalkoznunk kell a kérdéssel: egyrészt, mert megérdemeljük, hogy megtudjuk, vajon jobban sikerült-e a pandémia-szemeszter a korábbiaknál. Ha nem, akkor javítanunk kell az online rendszerükön, ha pedig jobban, akkor érdemes továbbfejleszteni, és akár nagyobb hangsúlyt adni neki. Másodsorban pedig azért, mert ha látjuk, hogy a hallgatók is pozitívnak érezték a megváltozott körülményeket, akkor ki kell használnunk ezt az élesedő, hallgatókért folytatott versenyben is, mint versenyelőny.

\section{A téma felvezetése, a vonatkozó szakirodalom bemutatása, értékelése}

Ahhoz, hogy egyáltalán online felsőoktatásról beszéljünk, nem csak a technikának, az oktatóknak és a módszereknek, de a befogadóknak, a hallgatóknak is készen kell állnia a fejlődésre. A legújabb (konnektivista) felfogás szerint a tanulás másokkal együttmüködő tudásépítés, amely során az ingerek a tanulók számára jelentős mértékben már egymástól érkeznek. (Siemens, 2005). Siemens szerint a szakértelem a tudásszükséglet azonosításának és a tudásforrások fellelhetőségének képességével egészül ki. A hagyományos felsőoktatásban a tudás forrása elsődlegesen a frontális tantermi oktatás, ahol a hallgató vagy a tudásátadás passzív befogadója, vagy - a legújabb oktatási módszereknek köszönhetően - maga is aktív részese a folyamatnak, akár egyéni, akár csoportos bevonódáson keresztuil. A mai egyetemi hallgatókra még az is jellemző, hogy intenzíven használják az internetet, azon keresztül kommunikálnak és szórakoznak. Egyes vélemények szerint azonban a jelenlegi „,netgenerációt” helyesebb lenne „médiagenerációnak” nevezni, mivel az internet által biztosított lehetőségeket csak a számukra legfontosabb tevékenységekhez, a kapcsolattartáshoz és a szórakozásukhoz használják, tanuláshoz szinte egyáltalán nem. Vagyis, nincs szó arról, hogy más gondolkodásmódjuk és tanulási szokásaik lennének, az internetet és az egyéb megoldásokat (email, chat, közösségi oldalak) pusztán mint médiumot használják. (Schulmeister, 2009; Bessenyei, 2010)

Az 1. táblázat rövid történeti áttekintést ad arról, hogyan fejlődött az online oktatás az elmúlt 40 évben. Az infokommunikációs technológiák átalakították a hallgatók elvárásait. Míg a hagyományos oktatás

- helyhez és az oktatói, hallgatói jelenléthez kötött,

- valós időben történik, 
- $\quad$ az oktató által kontrolláltan müködik és

- lineáris oktatási megoldásokat alkalmaz (Dabbagh és Nannaritland 2005),

addig az online oktatási és tanulási környezetben az új technológiai lehetőségeket kihasználva az aszinkron és valós idejü kommunikáció kötetlen és dinamikus lesz, sokféle pedagógiai gyakorlat, az aktív tanulás valósulhat meg, valamint a hallgatóközpontú pedagógiai attitüd válhat jellemzővé (Keengwe-Kidd 2010).

1. táblázat: Az online oktatás történeti áttekintése

\begin{tabular}{|l|l|l|}
\hline \multicolumn{1}{|c|}{ Időszak } & \multicolumn{1}{|c|}{ Fókuszpont } & \multicolumn{1}{c|}{ Oktatási sajátosság } \\
\hline $1975-1985$ & $\begin{array}{l}\text { Számítógéppel segített } \\
\text { oktatás }\end{array}$ & $\begin{array}{l}\text { Programozás a probléma megoldásához; helyi } \\
\text { felhasználó-számítógép interakció }\end{array}$ \\
\hline $1985-1990$ & $\begin{array}{l}\text { Számítógép-alapú } \\
\text { tréning, multimédia }\end{array}$ & $\begin{array}{l}\text { Interaktívmultimédia-használat; passzív } \\
\text { tanulás }\end{array}$ \\
\hline $1990-1995$ & $\begin{array}{l}\text { Webalapú oktatás és } \\
\text { tréning }\end{array}$ & $\begin{array}{l}\text { Internetalapú tartalomtovábbítás; aktív } \\
\text { tanulás; korlátozott végfelhasználói } \\
\text { interaktivitás }\end{array}$ \\
\hline $1995-2005$ & E-learning & $\begin{array}{l}\text { Internetalapú rugalmas kurzusok nagyobb } \\
\text { interaktivitással; online multimédia kurzusok; } \\
\text { távoli felhasználó-felhasználó kapcsolatok }\end{array}$ \\
\hline 2005 óta & $\begin{array}{l}\text { M-learning és } \\
\text { közösségi hálózatok } \\
\text { rendszerek, közösségi hálózati megoldások; } \\
\text { vezeték nélküli eszközök alkalmazása; a } \\
\text { hangsúly a tanuló mobilitásán van }\end{array}$ \\
\hline
\end{tabular}

Forrás: Keengwe-Kidd (2010) 534. old.

\section{A kutatás szükségessége, módszere}

Az online oktatásra való áttérés a tavaszi szemeszterben történt meg, már az oktatás megkezdése után. A kurzustartalom tervezése, valamint a kurzusfejlesztés - mint a képzés folyamatának első két eleme - tehát már megvalósult vagy éppen folyamatban volt. Az Edutus Egyetem már évek óta használja levelező és kedvezményes tanrendes hallgatói számára webináriumi rendszerét, amely, bár módszerét tekintve egy érdekes elegye a jelenléti, a webináriumi (vagyis valós idejü online kapcsoltatás + szeminarium) és az e-learninges (kész anyagok visszanézésének lehetősége kurzusvideó formájában) oktatásnak, az online oktatásra való kényszerü átálláskor ez óriási előnyt jelentett. Nem okozott problémát az online platform kiválasztása, hiszen adott volt erre a Skype vállalati verziója. Mindamellett hallgató oldalról, főleg a webináriumot kevesebbet, vagy egyáltalán nem használó nappali tagozatosok körében gondot okozhatott. hogy az online tanulásban a hallgatók függetlenebbek és felelősebbek a saját tanulási folyamataikért, mivel korlátozottabb a kapcsolat az oktatókkal és a hallgatótársakkal. 
Mi több, a diákok között találhatunk olyanokat is, akiket nem érdekelnek a különböző technikai eszközök, és kényelmesebbek számukra a hagyományos oktatási módszerek (Al-AdwanSmedley, 2012).

Egy másik, 2018-as magyarországi kutatás (Szelei, 2018) szerint a hagyományos értelemben vett, könyvből való tanulás háttérbe szorul. A hallgatók nem töltenek túl sok időt a tanulással, és alapvetően szeretnek a tanárok által összeállított slide-sorokból felkészülni. A válaszadók egyharmada használja az internetet az órákon az előadáshoz kötődően, a szemináriumokra való készülés pedig a válaszadók 65 százalékánál kevesebb, mint egy óra. 40 százalékuk otthon szeret tanulni, ehhez kétharmaduk az internet segítségét is igénybe veszi. A kutatásból kiderült, hogy a fiataloknak nincs igazi tanulási stratégiája, illetve az otthoni tanulásuk kevésbé aktív és hatékony. A válaszadók fele használ a tanuláshoz könyvet, saját jegyzetet, elsődleges forrásként a tanárok által biztosított slide-okat (Szelei 2018).

Ha az egyetem arra törekszik, hogy a külső környezeti adottságát figyelembe véve a versenykörnyezet is minél inkább lehetőséggé konvertálja, akkor érdemes megvizsgálni, milyen eredményekkel zajlott az elmúlt félévben az átállás mind hallgatói, mind oktatói oldalról.

A COVID 19 Global Student Survey eredményei szerint (Covid 19 Social Science Lab, 2020) Magyarország a világ országai közül az első helyen áll annak tekintetében, hogy a hallgatók saját véleményük szerint - növelni tudták teljesítményüket az új oktatási környezetben (3,05 / 5 értékelés), második helyen állnak hallgatói elégedettségben, ami a tananyag oktatóktól hallgatók felé történő prezentációját illeti (3,5 / 5 értékelés.). És a magyar hallgatók szintén második legjobbnak értékelik az egyetemek teljesítményét az új helyzetben (69\%). Vajon a globális felmérés eredményeit mennyire támasztja alá az Edutus hallgatóinak véleménye? Jobbnak vagy rosszabbnak ítélték meg az elmúlt hónapok oktatását?

A COVID-19 világjárványnak az Edutus Egyetem oktatására gyakorolt hatásának vizsgálatára 2020. júliusában került sor azzal a céllal, hogy hasznos információkat és javaslatot tudjak megfogalmazni az online oktatás továbbfejlesztésére, esetleg specializációjára, amelyet mind a járványhelyzet folytatásakor, de még inkább azt követően az megváltozott piaci környezetben tud majd az intézmény a hallgatókért folytatott versenyben használni. 
Az online kérdőíves megkérdezés során az egyetem összes hallgatóját és oktatóját bevontuk a kutatásba. A hallgatóknak szóló kérdőívet összesen 103-an töltötték ki, ez a teljes sokaság 15,2\%-a. (Az oktatói válaszok feldolgozása nem ennek a cikknek a témája.) Az kérdőív összeállítását megelőzte a hallgatók, illetve oktatók közötti nyílt válaszos véleménykérés is. A hallgatók esetében ez két online kurzuson történt hallgatói feladat keretében, oktatók esetében pedig emailen keresztül történt.

\section{A téma tárgyalása/ kutatási eredmények}

A válaszadók körében a képzés jellegét tekintve felülreprezentáltak voltak a müszaki, képzési helyszínt tekintve pedig a tatabányai hallgatók.

2. táblázat: A megkérdetettek és az összes hallgató oktatásdemográfiai adatai

\begin{tabular}{|l|c|c|c|}
\hline & $\begin{array}{r}\text { Válaszadók eloszlása } \\
\text { a mintában (\%) }\end{array}$ & $\begin{array}{c}\text { Eloszlás a teljes } \\
\text { sokaságban (\%) }\end{array}$ & Eltérés (\%) \\
\hline Müszaki képzés & 21,4 & 13,4 & $+8,0$ \\
\hline Gazdasági képzés & 78,6 & 86,6 & $-8,0$ \\
\hline & & & \\
\hline Alapszak & 83,5 & 79,2 & $+4,3$ \\
\hline Mesterszak & 2,9 & 2,3 & $+0,6$ \\
\hline Felsőoktatási szakképzés & 11,7 & 5,8 & $+5,9$ \\
\hline $\begin{array}{l}\text { Egyéb (szakirányú továbbképzés, } \\
\text { nemzetközi program képzése, } \\
\text { vendéghallgató) }\end{array}$ & 1,9 & 12,7 & $-10,8$ \\
\hline & & 52,8 & $-9,1$ \\
\hline Budapest & 43,7 & 36,1 & $+19,2$ \\
\hline Tatabánya & 55,3 & 11,1 & $-10,1$ \\
\hline $\begin{array}{l}\text { Egyéb (Sümeg, Tata, } \\
\text { Székelyudvarhely) }\end{array}$ & 1,0 & 62,7 & $+6,2$ \\
\hline & & 37,3 & $-6,2$ \\
\hline Levelező & 68,9 & & \\
\hline Nappali & 31,1 & 5 & \\
\hline
\end{tabular}

Forrás: saját kutatás

A hallgatók 10-es skálán összességében 7,83-ra értékelik a 2019/20-as tavaszi, online szemesztert. Azt, hogy egy szóval hogyan is élték meg ezt a félévet az 1. ábrán látható. 


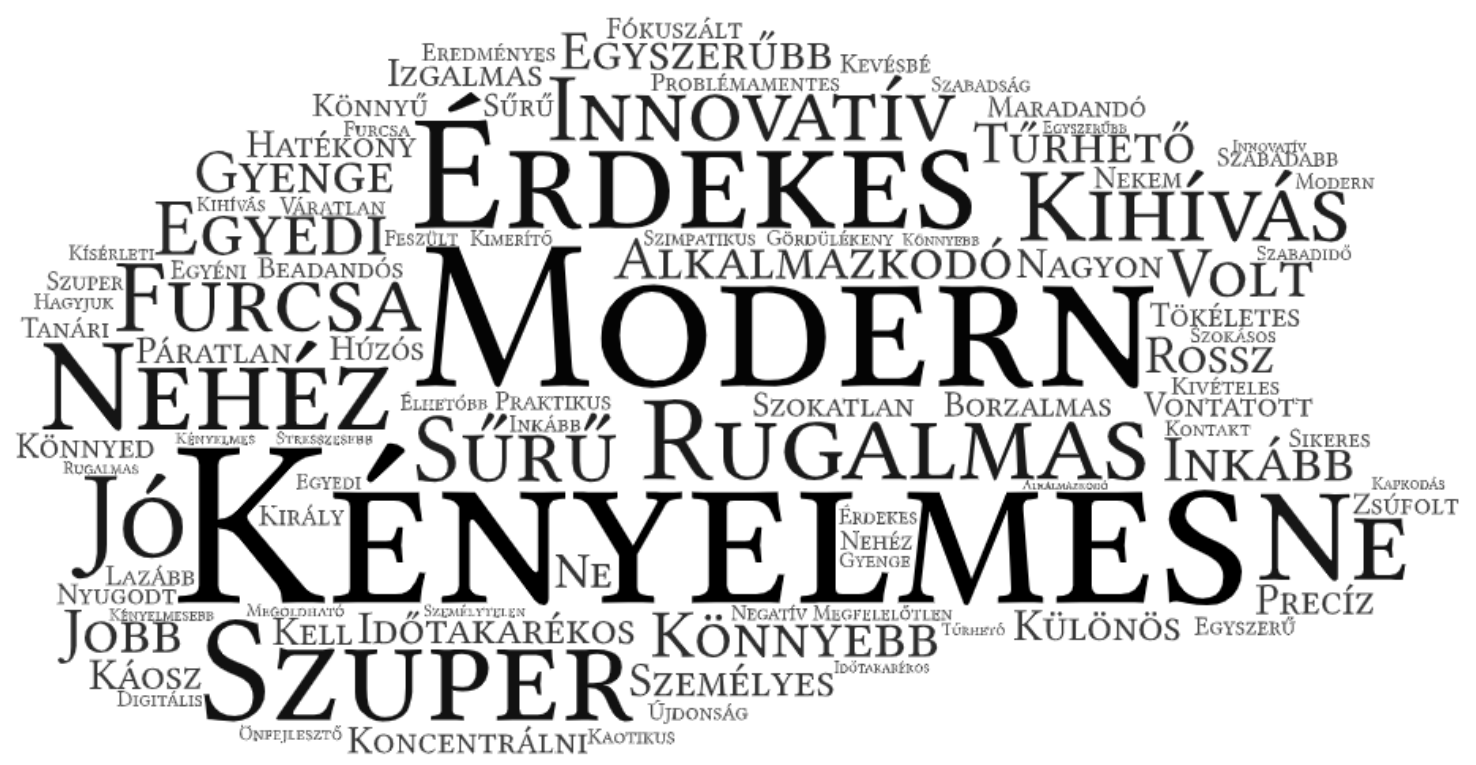

Forrás: saját kutatás

Összevetve ezt az eredményt a korábban már említett Global Student Survey ${ }^{1}$ (Covids Lab, 2020). nemzetközi átlagával, ott azok a hallgatók, akik a pandémia következében online oktatásra átállt egyetemek hallgatói, a valós idejű online videokonferenciát (amit az Edutus is használ) találták a legjobbnak, s az ezzel való elégedettségük (a 10-es skálának megfeleltetve) 6,58 volt.

Árnyaltabb képet kapunk, ha az elégedettségeket az oktatásdemográfiai ismérvek szerint is megvizsgáljuk. Ezek szerint a müszaki képzésben résztvevők elégedettsége magasabb a gazdasági képzésben résztvevőknél $(7,91-7,82)$. Mivel a müszaki hallgatók aránya a mintában a teljes sokaságénál magasabb volt, ez hatással volt az összelégedettségre is. Az alapképzésben résztvevők értékelése az átlagoshoz közelít $(7,85)$ a mesterképzésben résztvevők jelentősen elégedettebbek (9,63), míg a felsőoktatási szakképzésben képzésben résztvevők elégedetlenebbek $(6,75)$.

A Budapesti hallgatók jobbnak érzeték a félévet a tatabányiaknál $(8,16$ / 7,63), míg a levelezősök a nappalisoknál $(8,44$ / 6,50).

A hallgatók az online oktatás mellett és ellen felsorakoztatott legfőbb érvei a következők voltak (a kiemelteket a válaszadók több, mint 50\%-a említette).

\footnotetext{
${ }^{1}$ http://www.covidsoclab.org/first-findings/global-database/satisfaction-with-online-forms-of-lectures/
} 
3. táblázat: Az online oktatás mellett és ellen szóló érvek

\begin{tabular}{|c|c|}
\hline Mi szól az online oktatás mellett? & Mi szól az online oktatás ellen? \\
\hline $\begin{array}{ll}\text { - } & \text { Nem kellett utazni } \\
\text { - } & \text { Kényelmes és praktikus otthoni } \\
& \text { környezetben tanulni } \\
\text { - } & \text { Nagyon segítókészek voltak az } \\
& \text { oktatók } \\
\text { - } & \text { Rugalmasabb, de mégis órarend } \\
& \text { szerinti } \\
\text { - } & \text { A tanárok kreatívabbak voltak } \\
\text { - } & \text { Interaktív volt az oktatás } \\
\text { - } & \text { Kisebb volt a vizsgadrukk }\end{array}$ & $\begin{array}{l}\text { - A személyes kontakt hiánya } \\
\text { - } \quad \text { Technikai problémák } \\
\text { - A „számolós” tárgyaknál nehezebb volt a } \\
\text { megértés } \\
\text { - } \quad \text { Túl sok lett félév végére a beadandó } \\
\text { - } \quad \text { Hiányzott az egyetemi légkör és a társaság } \\
\text { - } \quad \text { Monotonabbak voltak az órák } \\
\text { - } \quad \text { Voltak tanárok, akik nagyon gyakorlatlanok } \\
\text { voltak az online oktatásban } \\
\text { - Egész nap a gép elött kellett ülni, sokszor nem } \\
\text { volt szünet az órák között }\end{array}$ \\
\hline
\end{tabular}

Forrás: saját kutatás

A levelezős hallgatók azt is kiemelték, hogy az eddigi webináriumi funkció jobban megvalósult a vizsgált félévben, korábban ugyanis, amikor párhuzamosan zajlott a jelenléti és a webináriumi oktatás, akkor őket nagyon zavarta, hogy az oktató a jelenlévőkkel is beszélget, ők ezt ugyanis nem hallják.

A hallgatók az online kurzusok minöségét kizárólag a tanárok személyének és kompetenciáinak tudták be. Nem befolyásolta véleményük szerint az oktatás minőségét a tantárgyi tartalom és a tananyagok. A matematika alapú tárgyaknál nehezebbnek tartották a felkészülést, az otthon tanulást és a tananyag megértését, de összességében a hallgatók $28 \%$-a, még nyílt kérdésre is azt válaszolta, hogy „nem volt olyan tantárgy, ami nehezebb lett volna online”.

Mivel többen hiányolták a személyes kontaktot, megkérdeztem, hogy az online órák során hogyan tarották a kapcsolatot az oktatóval, illetve a többi hallgatóval. Bár hiányolták a személyes beszélgetést, a kommunikációra mégis inkább a csetet használták. A csetelés a levelezősöknél kevésbé volt hangsúlyos kapcsolattartási forma, mint az alap, vagy felsőoktatási szakképzésben résztvevőknél, ők koruknál, illetve a korábbi webináriumos előéletük miatt, valamint munkahelyi tapasztalataik miatt könnyebben váltottak mikrofonon keresztül szóbeli beszélgetésre, közel 50\%-uk használta ezt a kommunikációs csatornát az órákon. 
2. ábra: Milyen eszközöket használt az online kommunikációra? (n=103)

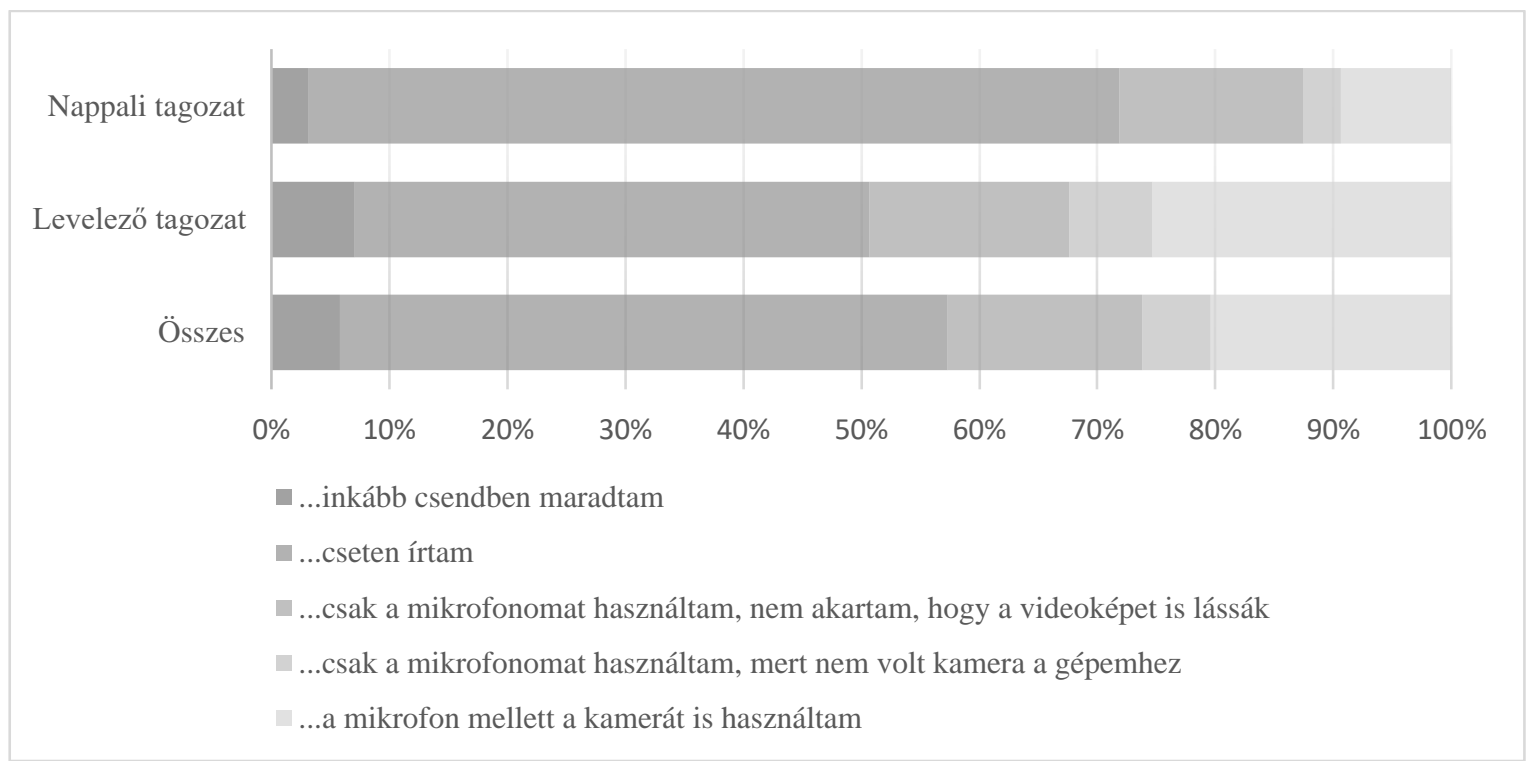

Forrás: saját kutatás

Az online oktatás részleteinek vizsgálatára ötfokozatú Likert skálát használtam. Legnagyobb kihívásként a hallgatók az önálló feladatmegoldás növekedését és a vizsgáztatást tartották.

\section{3. ábra: Mennyire ért egyet az ellentétes állításokkal}

\begin{tabular}{|c|c|c|}
\hline Az online órák unalmasabbak voltak. & 3,34 & Az online órák érdekesebbek voltak. \\
\hline $\begin{array}{r}\text { A tanárok rosszabb, élvezhetetlenebb órát } \\
\text { tartottak. }\end{array}$ & 3,53 & $\begin{array}{l}\text { A tanárok több új módszert bevetettek, hogy } \\
\text { érdekesebbek legyenek az órák. }\end{array}$ \\
\hline A tanárok elég sokat bénáztak a technikával & 3,73 & A tanárok jól kezelték a technikát. \\
\hline Sok gondom volt a technikával. & 3,86 & Részmeröl mindig rendben volt a technika. \\
\hline Nehezebben ment az online kommunikáció. & 3,54 & Élveztem az online kommunikációt. \\
\hline $\begin{array}{r}\text { Hiányzott a visszacsatolás, a személyes } \\
\text { kommunikáció. }\end{array}$ & 3,13 & $\begin{array}{l}\text { Remekül megoldottuk a kommunikációt az } \\
\text { online térben is. }\end{array}$ \\
\hline $\begin{array}{l}\text { Jellemzöbben kellett önállóan feladatokat } \\
\text { megoldanunk a félév folyamán. }\end{array}$ & 2,53 & Sok csapatmunkát végeztünk online is. \\
\hline Nehezebben ment az önálló tanulás. & 3,35 & $\begin{array}{l}\text { Könnyebben tudtam magamat fejleszteni, } \\
\text { könnyü volt a tanulás egyedül. }\end{array}$ \\
\hline $\begin{array}{l}\text { A számonkérés nehezebb volt, mert az online } \\
\text { vizsgák során a tanárok kevesebb időt adtak, } \\
\text { hogy ne tudjunk segítséget igénybe venni. }\end{array}$ & 3,04 & $\begin{array}{l}\text { A számonkérés könnyebb volt, mert könnyedén } \\
\text { tudtunk segítséget használni vizsga közben. }\end{array}$ \\
\hline $\begin{array}{l}\text { A vizsgaidőszak nehezebb volt, mert az } \\
\text { eddiginél több házidolgozatot kellett megírnunk. }\end{array}$ & 3,23 & $\begin{array}{l}\text { A vizsgaidőszak könnyebb volt, mert kevesebb } \\
\text { volt az írásbeli vizsga és több volt a beadandó } \\
\text { házidolgozat. }\end{array}$ \\
\hline $\begin{array}{r}\text { Ebben a félévben kevesebb tudást szereztem, } \\
\text { mint korábban }\end{array}$ & 3,28 & $\begin{array}{l}\text { Ebben a félévben több és értékesebb tudásra } \\
\text { tettem szert. }\end{array}$ \\
\hline $\begin{array}{r}\text { Összességében kevesebbet kaptam ebben a } \\
\text { félévben, mint az elözöben. }\end{array}$ & 3,31 & $\begin{array}{l}\text { Ebben a félévben több szolgáltatást kaptam, } \\
\text { mint korábban. }\end{array}$ \\
\hline
\end{tabular}

Forrás: saját kutatás 
4. táblázat: Online oktatás értékelése tagozatok és képzési formák szerint

\begin{tabular}{|c|c|c|c|c|c|c|c|}
\hline 1 & összesen & nappali & \begin{tabular}{|l} 
levelezö \\
\end{tabular} & \begin{tabular}{|c|} 
alap- \\
képzés
\end{tabular} & $\begin{array}{l}\text { mester- } \\
\text { képzés }\end{array}$ & \begin{tabular}{|c|} 
FSZ- \\
képzés
\end{tabular} & 5 \\
\hline $\begin{array}{r}\text { Az online órák } \\
\text { unalmasabbak voltak. }\end{array}$ & 3,34 & 2,84 & 3,56 & 3,40 & 4,00 & 2,67 & $\begin{array}{l}\text { Az online órák } \\
\text { érdekesebbek voltak. }\end{array}$ \\
\hline $\begin{array}{r}\text { A tanárok rosszabb, } \\
\text { élvezhetetlenebb órát } \\
\text { tartottak. }\end{array}$ & 3,53 & 2,97 & 3,79 & 3,55 & 3,67 & 3,42 & $\begin{array}{l}\text { A tanárok több új } \\
\text { módszert bevetettek, } \\
\text { hogy érdekesebbek } \\
\text { legyenek az órák. }\end{array}$ \\
\hline $\begin{array}{r}\text { A tanárok elég sokat } \\
\text { bénáztak a } \\
\text { technikával }\end{array}$ & 3,73 & 3,38 & 3,89 & 3,72 & 4,67 & 3,75 & $\begin{array}{l}\text { A tanárok jól kezelték } \\
\text { a technikát. }\end{array}$ \\
\hline $\begin{array}{r}\text { Sok gondom volt a } \\
\text { technikával. }\end{array}$ & 3,86 & 3,59 & 3,99 & 3,88 & 5,00 & 3,67 & $\begin{array}{l}\text { Részemről mindig } \\
\text { rendben volt a } \\
\text { technika. }\end{array}$ \\
\hline $\begin{array}{l}\text { Nehezebben ment az } \\
\text { online kommunikáció. }\end{array}$ & 3,54 & 3,09 & 3,75 & 3,53 & 5,00 & 3,33 & $\begin{array}{l}\text { Élveztem az online } \\
\text { kommunikációt. }\end{array}$ \\
\hline $\begin{array}{r}\text { Hiányzott a } \\
\text { visszacsatolás, a } \\
\text { személyes } \\
\text { kommunikáció. } \\
\end{array}$ & 3,13 & 2,63 & 3,35 & 3,14 & 4,33 & 2,75 & $\begin{array}{l}\text { Remekül megoldottuk } \\
\text { a kommunikációt az } \\
\text { online térben is. }\end{array}$ \\
\hline $\begin{array}{r}\text { Jellemzőbben kellett } \\
\text { önállóan feladatokat } \\
\text { megoldanunk a félév } \\
\text { folyamán. }\end{array}$ & 2,53 & 2,78 & 2,42 & 2,56 & 2,33 & 2,50 & $\begin{array}{l}\text { Sok csapatmunkát } \\
\text { végeztünk online is. }\end{array}$ \\
\hline $\begin{array}{l}\text { Nehezebben ment az } \\
\text { önálló tanulás. }\end{array}$ & 3,35 & 3,13 & 3,45 & 3,37 & 3,67 & 2,92 & $\begin{array}{l}\text { Könnyebben tudtam } \\
\text { magamat fejleszteni, } \\
\text { könnyü volt a tanulás } \\
\text { egyedül. }\end{array}$ \\
\hline $\begin{array}{r}\text { A számonkérés } \\
\text { nehezebb volt, az } \\
\text { online vizsgák során a } \\
\text { tanárok kevesebb időt } \\
\text { adtak, hogy ne } \\
\text { tudjunk segítséget } \\
\text { igénybe venni. }\end{array}$ & 3,04 & 2,88 & 3,11 & 3,09 & 3,00 & 2,50 & $\begin{array}{l}\text { A számonkérés } \\
\text { könnyebb volt, mert } \\
\text { könnyedén tudtunk } \\
\text { segítséget használni } \\
\text { vizsga közben. }\end{array}$ \\
\hline $\begin{array}{r}\text { A vizsgaidőszak } \\
\text { nehezebb volt, mert } \\
\text { az eddiginél több } \\
\text { házidolgozatot kellett } \\
\text { megírnunk. }\end{array}$ & 3,23 & 3,19 & 3,25 & 3,27 & 3,33 & 3,00 & $\begin{array}{l}\text { A vizsgaidőszak } \\
\text { könnyebb volt, mert } \\
\text { kevesebb volt az } \\
\text { írásbeli vizsga és több } \\
\text { a beadandó } \\
\text { házidolgozat. }\end{array}$ \\
\hline $\begin{array}{r}\text { Ebben a félévben } \\
\text { kevesebb tudást } \\
\text { szereztem, mint } \\
\text { korábban }\end{array}$ & 3,28 & 3,16 & 3,34 & 3,29 & 3,67 & 3,17 & $\begin{array}{l}\text { Ebben a félévben több } \\
\text { és értékesebb tudásra } \\
\text { tettem szert. }\end{array}$ \\
\hline $\begin{array}{r}\text { Összességében } \\
\text { kevesebbet kaptam } \\
\text { ebben a félévben, } \\
\text { mint az előzőben. }\end{array}$ & 3,31 & 2,94 & 3,48 & 3,40 & 4,00 & 2,58 & $\begin{array}{l}\text { Ebben a félévben több } \\
\text { szolgáltatást kaptam, } \\
\text { mint korábban. }\end{array}$ \\
\hline
\end{tabular}

Forrás: saját kutatás 
(A felsőoktatási szakképzésnél és a mesterképzéseknél is megjelentek különbségek, ezek azonban a kitöltők kis száma miatt nem tekinthető szignifikánsnak.)

Alapvető különbség tapasztalható a között, ahogy a nappali, illetve a levelező tagozatos diákok megélték az online félév tapasztalatait, úgy is fogalmazhatunk, hogy a nappali tagozatos hallgatóknak jóval nehezebb, a levelezősöknek viszont könnyebb félévük volt. Mindennek a hátterében a már müködő webináriumi rendszer áll, amelynek a nappali képzésben még nem voltak meg az elözményei, hagyományai, a levelezősök viszont ennek egy javított, egységes csak az online oktatásra optimalizált verzióját kapták meg a korábbi, több-célcsoportos, és sokszor blended oktatás helyett. Az is látható a véleményekből, hogy a hallgatók úgy érzik, az oktatók - éppen az új kihívások miatt - sokat foglalkoztak a tananyagokkal. Az online technikai eszközök hiányossága, illetve az oktatók tapasztalatlansága miatt a jelenléti óránál kicsit unalmasabbnak, ám a korábbi webináriumi rendszernél (ahol a jelenléti órát lehetett távolról követni, illetve vissza lehetett nézni a jelenléti óra felvételét) érdekesebb, színesebb lett az oktatás. A levelezősök, éppen az oktatási forma miatt, továbbá azért, mert ők jellemzően munka mellett tanulnak, ahol szintén egyre gyakrabban használják a kapcsolattártás online eszközeit, sokkal inkább rá vannak és voltak eddig is kényszerítve az egyéni feladatok megoldására és az önálló tanulásra, továbbá a régóta adott lehetőségek miatt rutinosabban kezelték az egyetem online rendszerét is.

Megváltozott a számonkérés rendszere is, sok oktató alkalmazta azt a módszert, hogy kevesebb időt hagyott a hallgatóknak egy-egy feladat megoldására, hogy azoknak ne legyen ideje segítséget igénybe venni, ezzel azonban gyakran azok sem tudtak megfelelően teljesíteni, akiknek nem állt szándékukban a külső támogatás igénybevétele.

Ha a befizetett tandíjnak az ellenértékét is nézzük, akkor bár a nappalisok itt is kedvezőtlenebb válaszokat adtak, mégis minden esetben az átlag feletti a félév során kapott hallgatói érték.

Megnött a hallgatói jelenlét a virtuális órákon. A hallgatók órai részvétele is okozott némi meglepetést: habár eleinte az oktatók a hallgatók lemorzsolódása miatt aggódtak, az órákat helyettesítő videokonferenciákon és a számonkéréseken is ritkábbak voltak a hiányzások a jelenléti oktatás időszakához képest. A változás hátterében azonban nem csak a távoktatásra való áttérés sikere áll, hanem a hallgatók bezártsága is: most ők sem tudnak az óra helyett dolgozni vagy szórakozni, jobban ráérnek és egyszerübbé is vált számukra otthonról becsatlakozni az órákra. 
Az órai aktivitásuk esetében már kevésbé érzékelhető ez a kedvező változás. Ennek hátterében a már említett eszközhiányok előfordulása mellett az is meghúzódik, hogy az interaktivitás új módja szokatlan és eleinte kellemetlen volt a hallgatók számára. Valószínü, hogy ha a félév nem a normális mederben kezdődött volna, a kétirányú kommunikáció még nehézkesebben müködött volna a személyes kapcsolatok teljes hiánya miatt.

A hallgatók tanácsokat is megfogalmaztak az oktatók felé, amiket megfontolni javasolnak arra az esetre, ha tovább folytatódna az online oktatás, vagy más formában (akár kiegészítésként) újra megjelenne. Javasolják az oktatóknak a cset, mint kommunikációs forma előnyben részesítését. Egyrészt ez illik leginkább a hallgatók mindennapi kommunikációs szokásaihoz, másrészt sokan azért (is) használják, hogy ne kelljen beleszólniuk az órába, vagy más szavába vágni. Ez az oktatóknak mindenképpen kihívás, amihez azonban a hallgatói élmények miatt érdemes alkalmazkodni. Az online módszer hozza a javaslatok következő csoportját is: több videó használatát, akár csak ppt-be szúrt linkekkel (a Skype talán egyetlen hibája egyébként, hogy nem lehet rajta a videót lejátszani), valamit több alkalmazást, animációkat, interaktív játékokat és a gamification minden formáját (!), pontgyüjtést, online teszteket stb., amelyek színesítik az órákat és ellensúlyozzák a diákoknak azt a kihívását is, hogy online oktatás esetében napi 8-10 órát ülnek kizárólag a monitor előtt. Javaslatok érkeztek még a számonkérések átgondolására, amire az szűkebb időkorlátot nem látják jó megoldásnak, valamint néhány technikai javaslat - elsősorban a videók visszanézhetősége okozott néhány tárgynál problémát.

\section{„Az Edutus az etalon”}

Végezetül megkérdeztem a diákokat, tudnak-e olyan rendszerről, felsőoktatási intézményről, ahol véleményük szerint jól, vagy az Edutusál jobban zajlott az online oktatás, hogy tanuljunk belőle: elmondhatom, hogy a diákok többsége azt jelezte, az Edutuson müködött a legjobban a rendszer, meglátszott, hogy van előzménye az online oktatásnak. Az egyetlen jógyakorlat, amely elhangzott, az az, amikor az oktatók online személyes konzultációra adnak időpontokat, amire elöre lehet jelentkezni, ha egy vagy több diák nem ért egy tananyagot vagy tananyagrészt. 


\section{Következtetések/összefoglaló}

A technika adott, még ha voltak is átmeneti problémák

Az online oktatás szoftveres feltételei már évek óta adottak az intézményben, még ha ez nem is volt mindenki számára nyilvánvaló. Bár a Skype használata volt kötelező minden online kurzuson, az oktatók számos más szoftverrel egészítették az oktatást, ehhez azonban a hallgatók - valószínüleg digitális írástudásuknak köszönhetően - rendkívül jól alkalmazkodtak. A hallgatók körében előfordult, hogy nem rendelkeztek megfelelő hardver eszközökkel az órák követésére. Bár a videokonferenciákat okostelefonokon és tableteken is lehetett követni, ezeken keresztül interakcióba lépni már nem olyan egyszerü, főleg, ha egyszerre több alkalmazást is kellett használni.

A tananyag a régi, csak a módszer változik, és ez óriási terhelés

A kutatás kitért az oktatói véleményekre is, bár ebben a cikkben csak a hallgatói oldalt vizsgáltam. (Készült egy kutatás az oktatói oldal véleményéről is, amely egy következő anyag tartalma.) Az azonban tény, hogy mivel a tananyagon és a követelményeken nem történt változtatás, csak az oktatás és a számonkérés módszerén, ezért az online oktatás a hallgatók és az oktatók számára is - sokszor váratlan - többletmunkát okozott. Egyes kutatások szerint ez az oktatóknál kétszeres-négyszeres terhelésnövekedést jelentett (Hajdú-Jandó, 2020).

További kutatási irány, hogy jelen kutatás eredményeit összehasonlítsuk a valós hallgatói eredményekkel, akár szakok, szakirányok szintjén. 


\section{Felhasznált irodalom}

1. Caron, P (2020): Coronavirus and the Great Online-Learning Experiment. TaxProf Blog. 17 March, https://taxprof.typepad.com/taxprof_blog/2020/03/coronavirus-andthe-great-online-learningexperiment.html 2020.07.25.

2. CovidSoclab.org: Global Student Survey http://www.covidsoclab.org 2020.07.25.

3. Daad.de [2020]: COVID-19 Impact on International Higher Education: Studies \& Forecasts. https://www.daad.de/en/information-services-for-higher-educationinstitutions/centre-ofcompetence/covid-19-impact-on-international-higher-educationstudies-and-forecasts 2020.07.25.

4. Dr. Jan Kercher/Barbara Westfeld (2020): "Targeted support for universities in crisis management" https://www2.daad.de/der-daad/daad-aktuell/en/77069-targeted-supportfor-universities-in-crisis-management/ 2020.07.25 .

5. Friesner, Tim. (2011). History of swot analysis. Marketing Teacher. 2000-2010. https://www.marketingteacher.com/history-of-swot-analysis/ 2020.07.25.

6. Hajdu M. - Jandó Z. (2020): Van olyan egyetem, ahol négyszeresére nőtt a terhelés a távoktatás miatt https://g7.hu/kozelet/20200503/van-olyan-egyetem-aholnegyszeresere-nott-a-terheles-a-tavoktatas-miatt/ 2020.07.25.

7. Hargitai D. M. - Sasné Grósz A. - Veres Z. (2020): Hagyományos és online tanulási preferenciák a felsőoktatásban - A COVID-járvány kihívásai in: Statisztikai Szemle, 98. évfolyam 7. szám 839-857. oldal http://www.ksh.hu/statszemle_archive/all/2020/2020_07/2020_07_839.pdf 2020.07.25. https://doi.org/10.20311/stat2020.7.hu0839

8. Jonathan Zimmerman (2020): Coronavirus and the Great Online-Learning Experiment https://www.chronicle.com/article/coronavirus-and-the-great-online-learningexperiment/ 2020.07.25.

9. Szelei I. (2018): A tanulási szokások vizsgálata felsőoktatásban tanuló hallgatók körében. Hadmérnök. 13. évf. 4. sz. 423-434. old. http://hadmernok.hu/184_34_szelei.pdf 2020.07.25. 